\title{
ANALISIS KEPEMILIKAN INSTITUSIONAL TINGGI DAN RENDAH TERHADAP KINERJA PERUSAHAAN DI INDONESIA
}

\author{
Christian Herdinata \\ Program Studi International Business Management \\ Universitas Ciputra \\ UC Town, Citraland, Surabaya
}

\begin{abstract}
This study examined based on data of companies in Indonesia about the relationship between institutional ownership and corporate performance. In particular, institutional ownership will be distinguished by a high institutional ownership and low institutional ownership in order to determine the specific impact of institutional ownership on the performance of companies in Indonesia. Data were analyzed using different test mean with a sample of 136 companies. This study shows that a high institutional ownership gives a higher impact on the performance of the company compared with a low institutional ownership. Therefore, it reinforces the finding that high institutional ownership impacts in its monitoring compared to low ownership and corporate performance.
\end{abstract}

\begin{abstract}
ABSTRAK
Penelitian ini menguji berdasarkan data perusahaan di Indonesia tentang hubungan antara kepemilikan institusional dan kinerja perusahaan. Secara khusus kepemilikan institusional akan dibedakan berdasarkan kepemilikan institusional tinggi dan kepemilikan institusional rendah dengan tujuan untuk mengetahui secara spesifik dampak dari kepemilikan institusional terhadap kinerja perusahaan di Indonesia. Teknik analisis data menggunakan uji beda rata-rata dengan jumlah sampel 136 perusahaan. Penelitian ini menunjukkan bahwa kepemilikan institusional yang tinggi memberikan dampak yang lebih tinggi terhadap kinerja perusahaan dibandingkan dengan kepemilikan institusional yang rendah. Oleh karena itu, hal ini memperkuat temuan bahwa kepemilikan institusional yang tinggi memberikan dampak dalam melakukan monitoring dibandingkan kepemilikan yang rendah terhadap kinerja perusahaan.
\end{abstract}

Keywords: institutional ownership, corporate performance, monitoring.

\section{PENDAHULUAN}

Penelitian yang dilakukan oleh beberapa peneliti mengenai pola non linier yang menunjukkan pengaruh kepemilikan institusional terhadap kinerja perusahaan masih terdapat perbeda- 
an. Beberapa peneliti menemukan hasil berbentuk cembung artinya pada awalnya positif kemudian negatif antara lain: McConnell and Servaes (1995); Faccio dan Lasfer (1999); De Miguel et al. (2003); Sanghoon (2008); Ruan et al. (2011); dan Bos et al. (2011). Sedangkan peneliti lain menemukan hasil berbentuk cekung artinya pada awalnya negatif kemudian positif antara lain: Cui and Mak (2002); Garcia-Meca and SanchezBallesta (2009); dan Wellalage and Locke (2011). Penelitian ini ingin menguji berdasarkan data perusahaan di Indonesia tentang hubungan antara kepemilikan institusional dan kinerja perusahaan. Secara khusus kepemilikan institusional akan dibedakan berdasarkan kepemilikan institusional tinggi dan kepemilikan institusional rendah dengan tujuan untuk mengetahui secara spesifik dampak dari kepemilikan institusional terhadap kinerja perusahaan di Indonesia. Penelitian ini diharapkan dapat memberikan manfaat khususnya dalam pembuktian peran kepemilikan institusional sebagai mekanisme kontrol dalam meningkatkan kinerja perusahaan.

\section{TINJAUAN PUSTAKA}

Perusahaan di Indonesia mempunyai komposisi struktur kepemilikan yang agak berbeda dari negara lain. Sebagian besar perusahaan mempunyai pemegang saham dalam bentuk institusi bisnis (perseroan terbatas) yang seringkali merupakan representasi dari pendiri perusahaan (Mahadwarta, 2004). Ismiyanti (2003) menemukan bahwa di Indonesia ratarata kepemilikan institusional internal pada periode 1997-2001 mencapai $66 \%$ dari total saham beredar. Hal ini menunjukkan bahwa $34 \%$ tersebar untuk investor publik (individu), manajemen, komisaris, dan kepemilikan institusional eksternal. Hal ini sangat berbeda dengan kondisi di Amerika Serikat bahwa kepemilikan institusional eksternal mencapai 52,36\% dari total saham beredar (Chen and Steiner, 1999). Hal ini menunjukkan bahwa di Indonesia struktur kepemilikan mengarah kepada prinsipal institusional yang mayoritas sebagai representasi dari pemegang saham pengendali dan prinsipal lainnya yang minoritas sebagai representasi dari pemegang saham publik. Akibatnya, pemegang saham mayoritas memiliki kendali mutlak dibanding pemegang saham minoritas, sehingga pemegang saham mayoritas bisa melakukan tindakan yang menguntungkan dirinya, tetapi merugikan pemegang saham minoritas. La Porta et al. (1999) menunjukkan bahwa perusahaan-perusahaan publik di Indonesia memiliki konsentrasi kepemilikan atau dikendalikan oleh pemegang saham besar. Oleh karena itu, konflik keagenan yang terjadi pada perusahaan publik di Indonesia adalah konflik antara prinsipal mayoritas yaitu representasi dari pemegang saham pengendali dan prinsipal minoritas sebagai representasi dari pemegang saham publik.

Konsentrasi kepemilikan oleh pemegang saham mayoritas bisa memicu terjadinya risiko ekspropriasi terhadap pemegang saham minoritas. Ekspropriasi merupakan cara memaksimumkan kesejahteraan sendiri dengan distribusi kekayaan dari pihak lain (Claessens et al., 2000). Ekspropriasi dapat dilakukan oleh pemegang saham mayoritas melalui kebijakan perusahaan. Kebijakan dalam mengelola aset dapat menjadi pemicu timbulnya perbedaan kepentingan. Konflik 
tentang pengelolaan aset apabila tidak diselesaikan dengan mekanisme yang benar, maka akan memunculkan biaya keagenan yang berdampak pada kinerja perusahaan. Konflik keagenan yang memunculkan biaya keagenan akan berdampak pada kinerja perusahaan. Oleh karena itu, perbedaan kepentingan yang menyebabkan konflik harus diselaraskan. Perbedaan kepentingan dapat dikurangi dengan cara menyatukan kepentingan (convergence), sehingga kedua pihak memiliki kepentingan yang sama. Kuan et al. (2000), Pedersen and Thomsen (2001), serta Davies et al. (2005) menggunakan persamaan regresi (simultan) menemukan bukti empris bahwa terdapat saling keterkaitan positif antara kepemilikan manajerial dan kinerja perusahaan dan hal ini dikenal dengan convergence hyphothesis. Di sisi lain, Morck et al. (1988) menemukan suatu penyimpangan terhadap convergence hyphothesis. Hasil studi mereka menunjukan bahwa pada tingkat kepemilikan yang rendah hingga moderat menunjukkan pola yang sejalan dengan peningkatan nilai perusahaan. Namun, pada tingkat kepemilikan yang semakin tinggi justru menurunkan nilai perusahaan, kemudian mengalami kenaikan kembali. Hal ini menunjukan kepentingan prinsipal dan agen bergeser ke arah penyimpangan (entrenchment) dan hal ini dikenal dengan entrenchment hyphothesis.

Kepemilikan yang semakin tinggi menyebabkan adanya pemegang saham pengendali yang memiliki kontrol. Pemegang saham pengendali yang memiliki kontrol sebenarnya memiliki insentif secara lebih dekat untuk mengawasi perusahaan serta manajemen yang memberikan pengaruh positif, tetapi sebaliknya pemegang saham pengendali juga berpotensi untuk berkonflik dengan pemegang saham lain, khususnya pemegang saham minoritas (Surya dan Yustiavandana, 2006). Konflik ini akan memberikan akibat buruk ketika pemegang saham pengendali perusahaan melakukan eksploitasi perusahaan yang dikontrolnya dengan biaya yang juga ditanggung para pemegang saham lain, khususnya para pemegang saham minoritas, sehingga dapat menurunkan kinerja perusahaan. Hal ini diperkuat oleh penjelasan Hermeindito (2002) bahwa potensi konflik keagenan semakin besar karena bentuk pelaporan kepemilikan di Indonesia tidak mewajibkan mencatumkan ultimate shareholders (pemilik akhir perorangan dari institusi yang memiliki saham di perusahaan lain).

\section{METODE PENELITIAN}

Data yang digunakan dalam penelitian ini yaitu data Laporan Keuangan perusahaan, antara lain: dari Neraca, Laporan Laba Rugi, Laporan Arus Kas, dan Catatan Atas Laporan Keuangan, serta data pasar modal. Seluruh data Laporan Keuangan diperoleh dari Indonesian Capital Market Directory (ICMD) periode 2001-2012 dan Indonesian Securities Market Database (ISMD) yang dipublikasikan oleh Fakultas Ekonomi Universitas Gadjah Mada, Indonesia. Selanjutnya, untuk data pasar modal diperoleh dari laporan dari Bursa Efek Indonesia (BEI).

Sampel yang digunakan dalam penelitian ini yaitu: (1) Perusahaan di Indonesia yang telah diaudit mulai tahun 2001 sampai dengan 2012 dan tidak termasuk dalam industri keuangan; (2) Perusahaan yang diteliti menyediakan informasi data Laporan 
Keuangan secara lengkap untuk semua periode penelitian; (3) Perusahaan yang diteliti tidak sedang mengalami proses akusisi, merger, dan delisting; (4) Perusahaan yang diteliti menye- diakan informasi data pasar modal untuk semua periode penelitian. Berikut ini proses pemilihan sampel yang telah dilakukan seperti terlihat pada Tabel 1.

\section{Tabel 1}

Proses Pemilihan Sampel

\begin{tabular}{|c|l|c|}
\hline No & \multicolumn{1}{|c|}{ Proses } & Jumlah \\
\hline 1 & $\begin{array}{l}\text { Perusahaan yang terdaftar di Bursa Efek Indonesia (BEI) } \\
\text { dan termasuk dalam perusahaan non keuangan serta telah } \\
\text { diaudit pada periode 1 Januari 2001 - 31 Desember 2012. }\end{array}$ & 177 \\
\hline 2 & $\begin{array}{l}\text { Perusahaan yang tidak memiliki data laporan keuangan } \\
\text { secara lengkap selama periode 1 Januari 2001 - 31 } \\
\text { Desember 2012. }\end{array}$ & (17) \\
\hline 3 & $\begin{array}{l}\text { Perusahaan yang menjalani proses akusisi, merger, dan } \\
\text { delisting pada periode 1 Januari 2001 - 31 Desember 2012. }\end{array}$ & (3) \\
\hline 4 & $\begin{array}{l}\text { Perusahaan yang tidak memiliki kelengkapan data pasar } \\
\text { modal pada periode 1 Januari 2001 - 31 Desember 2012. }\end{array}$ & (21) \\
\hline 5 & Sampel Akhir & 136 \\
\hline
\end{tabular}

Sumber: Data Diolah

Deskripsi statistik variabel-variabel penelitian pada sampel perusahaan dapat dijelaskan sebagai berikut: Inst_Own_Rendah = persentase kepemilikan institusional total yang diambil dari batas $1 / 3$ terendah sebanyak 45 perusahan. Inst_Own_Tinggi = persentase kepemilikan institusional total yang diambil dari batas $1 / 3$ tertinggi sebanyak 45 perusahan; Q (kinerja perusahaan $)=($ nilai pasar ekuitas + total utang) $)_{\mathrm{t}} /$ (total aset). Teknik Analisis yang digunakan adalah uji beda rata-rata dengan tingkat signifikan $5 \%$.

\section{HASIL ANALISIS DATA DAN PEMBAHASAN}

Berdasarkan hasil uji beda ratarata menunjukkan bahwa kepemilikan institusional yang rendah memiliki tingkat rata-rata 1,39 terhadap kinerja perusahaan. Di sisi lain, pada kepemilikan institusional yang tinggi memili- ki rata-rata 1,73 terhadap kinerja perusahaan. Hal ini menunjukkan bahwa kepemilikan institusional yang tinggi memberikan dampak lebih tinggi terhadap kinerja perusahaan dibandingkan dengan kepemilikan institusional yang rendah. Oleh karena itu, hal ini memperkuat temuan bahwa kepemilikan institusional yang tinggi memberikan dampak dalam melakukan monitoring dibandingkan kepemilikan yang rendah. Hasil uji beda ratarata dapat ditunjukkan pada Tabel 2 berikut ini.

Kepemilikan institusional akan sangat berkepentingan dengan kinerja perusahaan, karena sebagian besar kekayaan pemegang saham institusional terkait langsung dengan kekayaan perusahaan, sehingga kepemilikan institusional juga akan dirugikan, bila terjadi penurunan kinerja perusahaan. Duggal and Millar (1999) menjelaskan tentang dua argumen yang mendasari 
peran penting kepemilikan institusional dalam meningkatkan efisiensi pasar modal yaitu pertama, investor institusional dianggap memiliki kemampuan riset yang lebih baik, canggih, dan memadai dari pada analisis individu dalam melakukan analisis investasi; kedua, kepemilikan institusional yang tinggi merupakan insentif ekonomi yang kuat untuk melakukan pengawasan terhadap manajer. Selain itu, Crutchley et al. (1999) mengung- kapkan bahwa pemilik institusi dianggap memiliki kemampuan superior dalam mengendalikan manajemen daripada pemilik individu. Selanjutnya, Jiang dan Kim (2000) menemukan kepemilikan institusi meningkatkan konsentrasi kepemilikan dan berhubungan negatif dengan kinerja perusahaan. Oleh karena itu, keberadaan kepemilikan institusional yang semakin tinggi akan berpengaruh positif terhadap kinerja perusahaan.

Tabel 2

Hasil Uji Beda Rata-Rata

\begin{tabular}{|l|c|c|c|c|c|}
\hline \multicolumn{1}{|c|}{ Variabel } & N & Mean & $\begin{array}{c}\text { Std. } \\
\text { Deviation }\end{array}$ & Nilai t & Sig. \\
\hline \multicolumn{2}{|l|}{ Panel C : Q (Kinerja Perusahaan) } \\
\hline Inst_Own_Rendah & 45 & 1,39 & 0,91 & $-1,279$ & 0,204 \\
Inst_Own_Tinggi & 45 & 1,73 & 1,55 & & \\
\hline
\end{tabular}

Sumber: Data Diolah

Thomsen (2004) menemukan bahwa struktur kepemilikan terkonsentrasi oleh pemegang saham besar berhubungan non linier dengan nilai perusahaan, yaitu ketika struktur kepemilikan terkonsentrasi rendah, nilai perusahaan turun, tetapi ketika kepemilikannya makin besar, maka mereka akan melakukan internalisasi, sehingga mereka melindungi investasinya yang cukup besar dalam perusahaan. Hu and Izumida (2008) juga menemukan pengaruh non linier berbentuk $U$ antara konsentrasi kepemilikan dan kinerja perusahaan. Hal ini menunjukkan adanya trade-off antara efek ekspropriasi (expropriation effect) dan efek monitoring (monitoring effect), karena perubahan perilaku pemegang saham mayoritas pada tingkat konsentrasi kepemilikan yang berbeda. Menurut $\mathrm{Hu}$ dan Izumida
(2008) semakin tinggi konsentrasi kepemilikan, maka semakin kecil tindakan ekspropriasi oleh pemegang saham pengendali, karena meningkatnya biaya ekspropriasi yang mereka tanggung.

Kepemilikan institusional dapat mengurangi konflik keagenan sehingga meningkatkan kinerja perusahaan. Pengawasan tersebut menjadi relevan dilakukan oleh pemilik karena terkait dengan kekayaan yang terikat dengan perusahaan yang dimilikinya, sehingga melalui peningkatan kepemilikan institusional dapat mengurangi konflik keagenan yang muncul. Oleh karena itu, semakin tinggi kepemilikan institusional, maka mekanisme kontrol yang dilakukan oleh pemegang saham institusional semakin kuat, sehingga kinerja perusahaan meningkat karena konflik keagenan yang rendah, sehingga me- 
nimbulkan biaya keagenan yang relatif kecil. Beberapa peneliti telah menemukan hubungan secara non linier, antara lain: Cui and Mak (2002); Garcia-Meca and Sanchez-Ballesta (2009), dan Wellalage and Locke (2011) yang menemukan efek non linier pada hubungan antara kepemilikan institusional dan kinerja perusahaan, yaitu pada saat kepemilikan rendah memiliki efek negatif dan ketika kepemilikan tinggi memiliki efek positif.

\section{KESIMPULAN}

Penelitian ini menunjukkan bahwa kepemilikan instusional yang tinggi memberikan dampak yang lebih tinggi terhadap kinerja perusahaan dibandingkan dengan kepemilikan institusional yang rendah. Oleh karena itu, hasil penelitian ini memperkuat temuan bahwa kepemilikan institusional yang tinggi memberikan dampak dalam melakukan monitoring lebih tinggi dibandingkan kepemilikan yang rendah.

\section{SARAN}

Untuk penelitian selanjutnya disarankan dapat dilakukan dengan membandingkan kepemilikan manajerial yang tinggi dan rendah terhadap kinerja perusahaan.

\section{DAFTAR KEPUSTAKAAN}

Bos, Sebastian, Andrew Pendleton and Steve Toms, 2011, Governance Thresholds, Managerial Ownership and Corporate Performance: Evidence from The U.K., Working Paper No. 58, The University of York.

Chen, C.R. and T.L. Steiner, 1999, Managerial Ownership and Agency
Conflicts: A Nonlinear Simultaneous Equation Analysis of Managerial Ownership, Risk Taking, Debt Policy and Dividend Policy, The Financial Review 34, page 119-136.

Claessens, S., S. Djankov and L.H.P. Lang, 2000, The Separation of Ownership and Control in East Asian Corporations, Journal of Financial Economics 58, page 81112.

Crutchley, C.E., M.R.H. Jensen, J.S. Jahera and J.E. Raymond, 1999, Agency Problem and The Simultaneity of Financial Decision Making: The Role of Institutional Ownership, International Review of Financial Analysis 8/2, page 177197.

Cui, H. and Y.T. Mak, 2002, The Relationship Between Managerial Ownership and Firm Performance in High $R \& D$ Firms, Journal of Corporate Finance 8, page 313-336.

Davies, J. R., David Hiller and Patrick McColgan, 2005, Ownership Structure, Managerial Behavior and Corporate Value, Journal of Corporate Finance 11, page 645-660.

De Miguel, A., J. Pindado and C. De La Torre, 2003, Ownership Structure and Firm Value: New Evidence From The Spanish Corporate Governance System.

Duggal, Rakesh and James A. Millar, 1999, Institusional Ownership and Firm Performance: The Case of Bidder Return, Journal of Corporate Finance 5, page 103-117.

Faccio and Lasfer, 1999, Managerial Ownership, Board Structure and 
Firm Value: The UK Evidence, Bilkent University and Hacettepe University (Turkey).

García-Meca, Emma and Juan P. Sanchez-Ballesta, 2009, Corporate Governance and Earnings Management: A Meta-Analysis, Corporate Governance: An International Review, 17 (5).

Hermeindito, 2002, Financing Decision Relevancy: An Emphirical Evidence of Balancing Theory, Jurnal Ekonomi dan Bisnis, 2 (1), Februari, Unika Atma Jaya Jakarta, hal. 13-20.

Hu, Y. and S. Izumida, 2008, The Relationship Between Ownership and Performance: A Review of Theory and Evidence, International Business Research, 1, page 72-81.

Ismiyanti, F., 2003, Kepemilikan Manajerial, Kepemilikan Institusional, Risiko, Kebijakan Utang dan Kebijakan Dividen: Analisis Persamaan Simultan, Thesis Tidak Dipublikasikan, Pascasarjana Universitas Gadjah Mada.

Jiang, Li and Jeong-Bon Kim, 2000, Cross-Corporate Ownership, Information Asymmetry and The Usefulness of Accounting Performance Measures in Japan, International Journal of Accounting 35, (1), page 85-98.

Kuan, Ruth Tan Seow, Chng Pheng Lui and Tan Tee Ween, 2000, CEO Share Ownership and Firm Value, Working Paper, August 11, Department of Finance and Accounting, Faculty of Business Administration, National University of Singapore 17, Law Link, Singapore 117591.

La Porta, R., F. Lopez-De-Salines and A. Shleifer, 1999, Corporate Ownership Around the World, Journal of Finance LIV/2, page 471-517.

Mahadwartha, P. A., 2004, Pengawasan dan Pengikatan Berbasis Kepemilikan Institusional Internal, Disertasi Tidak Dipublikasikan, Pascasarjana Universitas Gadjah Mada.

McConnell, J.J. and H. Servaes, 1995, Equity Ownership and The Two Faces of Debt, Journal of Financial Economics, 39, page 131-157.

Morck, Randall, Andrei Shleifer and Robert W. Vishny, 1988, Management Ownership and Market Valuation: An Emphirical Analysis, Journal of Financial Economics, 20, page 293-315.

Pedersen, Torben and Steen Thomsen, 2001, The Causal Relationship Between Insider Ownership, Owner Identity, and Market Valuation among The largest European Companies, Working Paper Series WP 15-2001, Departement of International Economics and Management Copenhagen Business School, Howitzvej 60, 2000 Copenhagen F.

Ruan, Tian and Ma, 2011, Managerial Ownership, Capital Structure and Firm Value: Evidence from China's Civilian-run Firms, Australian Accounting Business and Finance Journal, Vol. 5, No. 3, page 73-92. 
Sanghoon, Lee, 2008, Ownership Structure and Financial Performance: Evidence from Panel Data of South Korea, Forthcoming in Corporate Ownership and Control, Vol. 6, No. 2.

Surya and Yustiavandana, 2006, Penerapan Good Corporate Governance: Mengesampingkan Hak-Hak Istimewa Demi Kelangsungan Usaha, Kencana, Jakarta.

Thomsen, S., 2004, .Blockholder Ownership, Dividends, and Firm Value in Continental Europe, Department of International Economics and Management, Copenhagen Business School.
Wellalege and Locke, 2011, Ownership Structure and Firm Financial Performance: Evidence from Panel Data in Sri Lanka, Journal of Business Systems, Governance and Ethics, Vol. 7, No. 1. 